\title{
PENINGKATAN KUALITAS PEMBELAJARAN LISTRIK DINAMIS MELALUI IMPLEMENTASI VIRTUAL LABORATORIUM BERBASIS KOMPUTER DI SMP NEGERI 9 TEBING TINGGI
}

\author{
Rusti Lumban Gaol \\ Guru SMP Negeri 9 Tebing Tinggi Propinsi Sumatera Utara \\ rstlg@ymail.com
}

\begin{abstract}
Abstrak : Penelitian ini bertujuan untuk meningkatkan kualitas pembelajaran listrik dinamis melalui implementasi virtual laboratorium berbasis komputer. Implementasi virtual laboratorium berbasis komputer merupakan solusi tidak tersedia fasilitas laboratorium yang memadai dalam pembelajaran listrik dinamis di SMP negeri 9 Tebing Tinggi. Penelitian ini adalah penelitian tindakan kelas, yang dirancang mengikuti Model Kemmis dan Mc Taggart yang meliputi serangkaian yang saling terkait (berkesinambungan), setiap siklus terdiri dari 3 kegiatan yaitu perencanaan, tindakan, observasi dan refleksi yang diikuti oleh perencanaan pada siklus berikutnya dengan memanfaatkan hasil refleksi sebelumnya. Temuan penelitian menunjukkan: Pembelajaran Listrik dinamis dengan implementasi virtual laboratoratorium berbasis komputer dapat meningkatkan kualitas belajar siswa dibuktikan dengan meningkatnya hasil belajar setiap siklus yaitu dari rata-rata 51,08 menjadi 71,13 menjadi 83,35 dan pembelajaran ini juga dapat meningkatkan minat belajar siswa, penguasaan konsep, keterampilan berpikir kreatif dan keterampilan proses sains $\mathrm{Hal}$ ini mengimplikasikan bahwa dengan implementasi virtual laboratorium berbasis komputer dapat meningkatkan kompetensi, persepsi atau tanggapan yang positif terhadap pembelajaran tersebut.
\end{abstract}

Kata Kunci : virtual, laboratorium berbasis komputer, kulaitas belajar

\begin{abstract}
This study aims to improve the quality of learning dynamic power through the implementation of computer-based virtual labs and overcome one of the difficulties faced by students when studying the dynamic power. Implementation of computer-based virtual labs is not a solution available adequate laboratory facilities in the dynamic power of learning in junior high school 9 Cliff High. This research is a classroom action research (classroom action research), which is designed to follow the model Kemmis and Mc Taggart which includes a series of interrelated (continuous), each cycle consisting of three activities, namely planning, action, observation and reflection, followed by the planning cycle next by utilizing the results of the previous reflection. The research findings indicate. Electricity learning dynamic with the implementation of computer-based virtual laboratoratorium can improve the quality of student learning evidenced by increasing learning outcomes of each cycle is an average of 51.08 into 83.35 and 71.13; and into this learning can also increase student interest, mastery of concepts, creative thinking skills and science process skills This implies that the implementation of computer-based virtual labs can improve the competence, perception or a positive response to the study.
\end{abstract}

Keywords: virtual laboratory of computer-based, quality learning

\section{PENDAHULUAN}

Belajar dengan memanfaatkan software komputer akan lebih efektif dibanding dengan alat bantu lainnya Salah satu cara untuk membuat proses pembelajaran menjadi menarik, siswa aktif, tidak membosankan, penyajian konsep jelas, dapat diulang-ulang sendiri, dilengkapi dengan latihan soal dan pembahasan yaitu menggunakan media komputer. Komputer mampu menggambarkan fenomena fisika mendekati kejadian sesungguhnya. Pembelajaran cenderung materi sentris sehingga terpisah dengan kenyataan di lapangan. Pembelajaran fisika siswa mendapat nilai baik, namun di rumah bila lampu mati, kabel setrika putus, siswa tidak bisa berbuat apa-apa. Jika siswa disuapi saja, maka kreativitasnya tidak muncul. Tidak ada minat, rasa tertarik, kreativitas dalam pembelajaran. 
Wawasan siswa terpotong-potong atau mati atau menjadi dead knowledge.

Praktek harus diadakan dan tidak harus di dalam kelas, bisa juga dalam bentuk tugas, atau proyek. Untuk meminimalisasi kesalahan konsep, guru dapat mengembangkan media bahan ajar yang di dalamnya terdapat konsep dan visualisasi bahan ajar sehingga mudah dipahami siswa dengan benar.

Optimalisasi penggunaan bahan ajar berbasis multimedia semacam ini akan menyenangkan siswa dan berpeluang mendatangkan hasil belajar yang meningkat baik kognitif, afektif maupun psikomotorik. Sekolah tidak mampu memfasilitasi siswa dengan sarana belajar atau praktik laboratorium yang mendukung sesuai dengan perkembangan jaman. Terbatasnya pendanaan menyebabkan sekolah tidak mampu menyediakan sarana belajar praktik laboratorium yang memadai. Akibatnya, mutu pendidikan siswa dan lulusan masih jauh dari harapan.

Permasalahan ini seharusnya dapat diatasi dengan pengembangan materi ajar dalam bentuk Virtual Laboratorium berbasis komputer dalam pembelajaran, terutama tidak tersedianya fasilitas laboratorium yang memadai. Pembelajaran dengan Virlab didasarkan dengan pengelolaan kurikulum tingkat satuan pendidikan (KTSP) 2006. Pada tataran implementasi kurikulum ini dituntut kreativitas guru di dalam memberikan pengalaman belajar yang dapat meningkatkan kompetensi peserta didik, karena betapapun baiknya kurikulum yang telah direncanakan pada akhirnya berhasil atau tidaknya sangat tergantung pada sentuhan aktivitas dan kreativitas guru sebagai ujung tombak implementasi suatu kurikulum.

Pengembangan pengalaman belajar perlu untuk dikembangkan melalui upaya penyediaan sarana pendidikan, metode pengajaran yang relevan serta strategi pembelajaran yang lebih tepat. Proses pembelajaran yang dirancang dengan baik akan meningkatkan kualitas hasil belajar. Variabel yang mempengaruhi perilaku belajar adalah kondisi pembelajaran, metode pembelajaran dan hasil pembelajaran (Reigeluth,1983:18). Konsekuensinya adalah perlu dipikirkan pemanfaatan komputer tersebut untuk keperluan peningkatan proses belajar mengajar. Belajar dengan memanfaatkan software komputer akan lebih efektif dibanding dengan alat bantu lainnya. Ini selaras dengan pandangan Heinich (1993:215) yang mengatakan bahwa komputer dapat memperkaya teknik pengajaran, dan melalui komputer sebagai pelengkap dalam penyampaian pengajaran yang berkesan dan bermutu. (Sharon, 2012:7)

Listrik dinamis sebagai salah satu pokok bahasan pada IPA khususnya fisika sangat membutuhkan praktikum atau eksperimen. Namun, minimnya sarana penunjang kerap kali menjadi penghambat khususnya di sekolah menengah pertama (SMP). Apalagi, investasi alat-alat laboratorium membutuhkan biaya yang tak sedikit dan tidak heran kalau lantas elektronika industri yang seharusnya menjadi ilmu praktek justru menjadi ilmu teoritis (Suyudi, 2007).

Perancangan virtual laboratorium merupakan solusi tersebut sehingga diperlukan adalah cara penyampaian bahan ajar kepada peserta didik dengan menggunakan perangkat multimedia (bunyi; gambar/grafik dan animasi) dan software pembelajaran, seperti: Matlab, Electronic Workbench, LegoCAD, dan Car Builder, Multisim, Etab, Psim, macromedia Flash, Easy Java Simulations (Ejs) yang didesain sedemikian rupa dengan tujuan melakukan beberapa aktivitas belajar secara virtual yang sama dengan aktivitas belajar di dalam laboratorium secara actual (Ágnes, 2005). Software (perangkat lunak) sebagai alat desain virtual laboratorium untuk menciptakan simulasi peristiwa melalui komputer dengan mudah, cepat dan tepat

Mengapa komputer berbasis simulasi menjadi sangat penting dalam bidang teknik kelistrikan atau elektronika?, salah satu sebabnya ialah bahwa kebanyakan rangkaian elektronika berorientasi terhadap keluaran (output) yang dihasilkan sehingga perlu mengetahui secara cepat mendapatkan hasilnya, selain itu analisis perhitungan yang membutuhkan waktu dan tenaga begitu banyak, dan juga cakupan rangkaian elektronika sangat luas dan selalu berubah sesuai dengan kebutuhan akan keadaan yang diinginkan

Di bidang pendidikan virtual laboratorium bisa dimanfaatkan sebagai sarana pembelajaran efektif yang menghubungkan guru dengan murid sekaligus menjadi sarana untuk mengangkat potensi serta kreativitas siswa. Dengan virtual laboratorium dapat juga dimanfaatkan sebagai sarana untuk menanamkan konsep dalam pebelajaran, menurut Bruner dalam Arsyad (2002:7) bahwa ada tiga tingkat utama modus belajar, yaitu pengalaman langsung (enactive), pengalaman 
piktoral/gambar (iconic), dan pengalaman abstrak (symbolic). Ketiga tingkatan pengalaman ini saling berinteraksi dalam upaya memperoleh pengalaman baru.

Pembelajaran adalah suatu proses penciptaan lingkungan yang memungkinkan terjadinya proses belajar. Belajar dalam pengertian aktivitas dari peserta didik (pelajar) dalam berinteraksi dengan lingkungan yang menghasilkan perubahan perilaku yang bersifat relatif konstan. Belajar dilakukan adalah untuk mencari; (a) Pengetahuan, (b) Ketrampilan, (c) Teknik, (d) Sikap, (e) Pengalaman Meningkatkan kualitas pembelajaran menjadi perhatian apabila dikaitkan dengan perluasan dan pembaharuan pendidikan. Ada beberapa kontribusi teknologi informasi dan komunikasi dalam membantu meningkatkan kualitas pembelajaran, yaitu (a). peningkatan motivasi belajar peserta didik; (b). Memfasilitasi pencapaian kompetensi dasar, dan (c). memperkuat pelatihan bagi para guru. Potensi setiap teknologi sangat bervariasi tergantung pada bagaimana memanfaatkannya.

Merujuk dari krakteristik permasalahan dalam pembelajaran Lisrik Dinamis dan juga mencermati inovasi pembelajaran berbasis Teknologi Informasi, dapat disimpulkan bahwa dengan suplemen virtual laboratorium berbasis komputer dalam pembelajaran Listrik Dinamis dapat digunakan untuk meningkatkan kualitas pembelajaran dan juga dapat meningkatkan prestasi belajar siswa kelas IX-5 SMP Negeri 9 Tebing Tinggi.

Dari permasalahan yang telah diuraikan pada latar belakang di atas, maka rumusan permasalahan pada penelitian ini ádalah : (1) Apakah implementasi virtual laboratorium berbasis komputer dalam pembelajaran listrik dinamis dapat digunakan untuk meningkatkan kualitas belajar siswa kelas IX-5 SMP Negeri 9 Tebing Tinggi?, (2) Sejauhmanakah implementasi virtual laboratorium berbasis komputer dapat mengatasi kesulitan belajar listrik dinamis di SMP Negeri 9 Tebing Tinggi?, (3) Apakah pembelajaran listrik dinamis dengan menggunakan virtual laboratorium berbasis komputer dapat meningkatkan respon positif?

Berdasarkan perumusan masalah, maka tujuan penelitian ini adalah: (1) Untuk mengetahui dampak implementasi virtual laboratorium berbasis komputer dalam pembelajaran Listrik dinamis dalam meningkatkan kualitas belajar Fisika pada siswa
SMP Negeri 9 Tebing Tinggi, (2) Menemukan salah satu solusi untuk mengatasi kesulitan belajar Listrik Dinamis pada siswa SMP Negeri 9 Tebing Tinggi, (3) Mengetahui tanggapan siswa terhadap pembelajaran implementasi virtual laboratorium berbasis komputer yang diterapkan.

\section{METODE}

Penelitian ini dilaksanakan di SMP Negeri 9 Tebing Tinggi. Subjek dalam penelitian ini adalah siswa kelas IX-5 SMP Negeri 9 Tebing Tinggi, Sumatera Utara Tahun ajaran 2012/2013. Sebanyak 37 orang terdiri dari 27 orang laki-laki dan 10 orang perempuan. Peneliti memilih kelas ini secara acak karena di SMP Negeri 9 tidak ada kelas unggulan, semua kelas sama.Rancangan Penelitianini adalah penelitian tindakan kelas (classroom action research), yang dirancang mengikuti Model Kemmis dan Mc Taggart yang meliputi serangkaian yang saling terkait (berkesinambungan).

Secara garis besar prosedur penelitian direncanakan menggunakan tiga siklus, dimana tiap siklus mempunyai empat tahapan, yaitu: (1) Menemukan dan memahaman suatu permasalahan sehingga dapat dibuat rencana strategi pemecahannya (Reconnaissance and Plan), (2) implementasi perencanaan dalam bentuk tindakan (Action), (3) Selama proses implementasi dilaksanakan, maka dilakukan pengamatan dengan menggunakan format monitoring dari implementasi (Observasi), (4) melihat sejauh mana tingkat pencapaian akibat implementasi tersebut (Reflect).

Data yang diperlukan untuk menjawab permasalahan yang ada, diidentifikasi secara khusus pada tiap-tiap siklus pembelajaran. Instrumen data yang digunakan adalah hasil belajar siswa, kinerja siswa melalui implementasi virlab dan hasil observasi perilaku siswa selama pembelajaran.Data ini dianalisis secara deskriptif. Secara keseluruhan pengolahan dan analisis data dari tiap-tiap pembelajaran dalam penelitian menempuh langkah-langkah sebagai berikut :

Siklus 1: (1) Menemukan ide atau gagasan, yaitu: untuk peningkatan kualitas pembelajaran dan hasil belajar listrik dinamis, dalam hal ini digunakan virtual laboratorium (virlab) berbasis komputer sebagai suplement pembelajaran listrik dinamis. Inovasi pembelajaran ini dikembangkan adalah disebabkan keterbatasan peralatan praktikum, 
waktu belajar, rendahnya kualitas pembelajaran elektronika dan pencapaian hasil belajar. (2) Penjajakan (Reconnaissance), yaitu: enganalisis prinsip mendasar dari perbaikan kualitas pembelajaran dan hasil belajar listrik dinamis, (3) perencanaan umum Perbaikan Kualitas Pembelajaran, yaitu: (a) merumuskan tujuan pembelajaran, (b) Menjajaki dan menetapkan materi pembelajaran listrik dinamis, (c) Membuat silabus dan RPP listrik dinamis, (d) Memilih Software engineering atau software educational yang akan digunakan dalam pembelajaran listrik dinamis, (d) Desain dan pembuatan modul modul pembelajaran dalam bentuk virlab berbasis komputer dalam kemasan $\mathrm{CD}$, (e) Implementasi Virtual Laboratorium berbasis komputer dalam pembelajaran listrik dinamis di kelas, (4) tindakan (Action), yaitu: (a) Siswa menggunakan modul Virtual Laboratorium berbasis komputer dalam belajar listrik dinamis pada setiap pokok bahasan, (b) Siswa melakukan aktivitas belajar dalam hal membuat desain rangkaian, menentukan komponen komponen elektronika, perakitan, pemasangan virtual instrumen, mengadakan pengukuran dan analisis, (c) Pelaporan aktivitas belajar, (d) mengerjakan soal yang diberikan oleh guru secara tertulis atau dengan menggunakan perangkat software komputer. (5) Observasi, yaitu: Mengadakan pengamatan kepada siswa dalam belajarnya akibat penggunaan virtual laboratorium berbasis komputer sebagai suplement dalam pembelajaran listrik dinamis. Pengamatan ini dilakukan terhadap efektivitas modul virlab dan juga terhadap masalah masalah yang timbul yang menghambat kemajuan belajar siswa. Hal ini dilakukan siswa didalam lembar monitoring implementasi virlab berbasis komputer. (6) Refleksi, yaitu: Hasil implementasi virtual laboratorium berbasis komputer dalam pembelajaran listrik dinamis akan dijajaki pengaruhnya terhadap peningkatan kualitas pembelajaran dan juga hasil belajar yang dicapai oleh siswa. Selain itu akan dijajaki kendala kendala yang menghambat kemajuan belajar siswa. Temuan dalam refleksi ini akan menjadi masukan pada siklus selanjutnya.

Siklus 2: (2) revisi Modul Virtual Laboratorium berbasis komputer dalam pembelajaran listrik dinamis, yaitu: masalah yang mengakibatkan kesulitan belajar menggunakan virlab yang ditemukan dari refleksi pembelajaran pada siklus 1 , diadakan perbaikan baik isi (materi) dan juga tingkat kesulitan dari materi pembelajaran maupun perbaikan modul virtual laboratorium (virlab) dengan tujuan, agar tercapainya kualitas pembelajaran yang tinggi dan tercapainya hasil belajar yang tinggi, (1) rencana Perbaikan, yaitu: (a) Memperbaiki modul virtual laboratoium berbasis komputer yang digunakan sebagai suplemen pembelajaran listrik dinamis (b) Mengadakan buku panduan di dalam melaksanakan pembelajaran, (3) tindakan Hasil Perbaikan, yaitu: siswa menggunakan virtual laboratorium berbasis komputer dalam pembelajaran siswa pada pembelajaran listrik dinamis dengan menggunakan buku panduan, (4) observasi atau monitoring pembelajaran virlab, yaitu: Mengadakan pengamatan kepada siswa dalam belajarnya akibat penggunaan virtual laboratorium berbasis komputer sebagai suplement dalam pembelajaran listrik dinamis. Pengamatan ini dilakukan terhadap efektivita modul virlab dan juga terhadap masalah masalah yang timbul yang menghambat kemajuan belajar siswa. Hal ini dilakukan guru didalam lembar monitoring implementasi virlab berbasis komputer.

Siklus 3: Pada siklus ke tiga diadakan perbaikan peningkatan kualitas pembelajaran dan hasil belajar, selanjutnya diadakan implementasi dari virlab. Hasil yang didapat dari siklus tiga ini yang berupa hasil penelitian tindakan kelas adalah: (a) Terdapatnya perangkat pembelajaran yang berupa Modul Virtual Laboratorium berbasis komputer dalam bentuk CD, (b) Terdapatnya RPP, Silabus dan buku panduan menjalankan CD Virlab, (c) Terdapatnya hasil belajar listrik dinamis yang tinggi yang berupa pengetahuan dan keterampilan siswa dalam bidang elektronika dan serta kemampuan membuat aplikasi. 


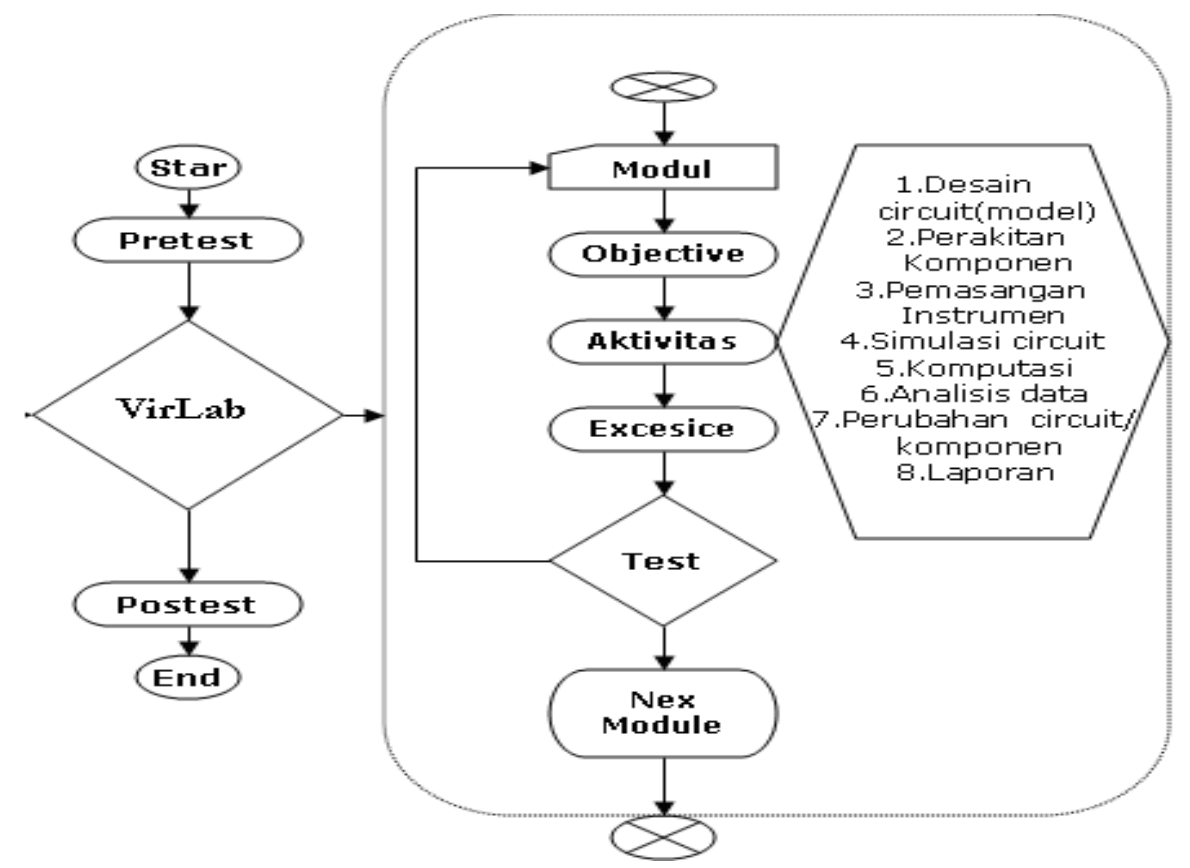

Gambar 1. Aktivitas Virlab dalam Pembelajaran

\section{Implementasi Virtual Laboratorium Berbasis Komputer}

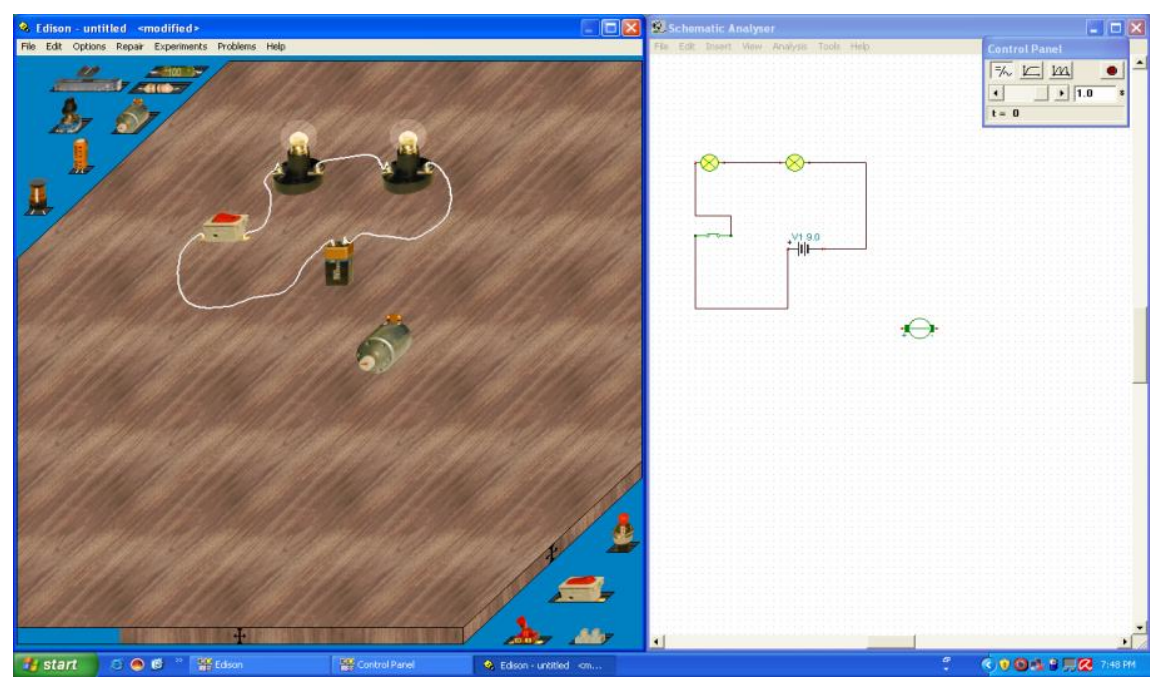

Gambar 2. Pembelajaran konsep hubungan seri dengan Virtual Laboratorium berbasis komputer

Prosedur kerja

1. Open Demo virtual (double clik)

2. Insert Komponen yang dibutuhkan dan tempatkan pada lembar kerja Edison versi 4.0

3. Susunlah rangkain listrik seperti pada gambar 4 (hubungan seri)

4. Hubungkan komponen komponen tersebut dengan menarik garis dari tiap ujung dari kutup komponen komponen dengan menempatkan cursor mouse dari yang dihubungkan
5. Gerakkan saklar dengan mouse atau clik Run dari toolsbar yang tersedia dan catat hasilnya pada lembar kerja.

6. Jika sakelar dalam keadaan terbuka, apakah kedua lampu menyala? Lalu, ketika sakelar S ditutup, apa yang terjadi?

7. Berdasarkan analisis di atas, buatlah kesimpulan.

\section{HASIL DAN PEMBAHASAN \\ Hasil \\ Siklus I \\ Data yang didapat dari kegiatan pembelajaran pada siklus I adalah sebagai}


berikut : (1) Siswa masih terbiasa dengan pengajaran pembelajaran yang dilakukan guru yaitu berpusat pada guru, jadi ketika pembelajaran dengan implementasi virtual laboratorium berbasis komputer disajikan siswa belum terfokus akibat kurang mampu untuk mengoperasikan software, (2) hasil evaluasi yang dilakukan guru setelah pembelajaran berlangsung, terjadi peningkatan dari test awal dapat dilihat pada tabel 1 namun peningkatan ini belum berarti apa-apa karena rata-rata hasil belajar siswa 51,08 \%, (3) hasil lembar monitoring implementasi virlab berbasis komputer yang menunjukkan penilaian kinerja siswa ada respon yang positif dari siswa terhadap implementasi virtual laboratorium berbasis komputer dapat dilihat pada tabel 2, tetapi masih banyak terdapat kesalahan akibat siswa tergesa-gesa mengerjakan modul.

Dari hasil refleksi disimpulkan bahwa untuk mencapai kualitas pembelajaran yang tinggi maka : (1) guru menjelaskan tujuan pembelajaran pada kegiatan yang akan dilakukan (2) Guru menjelaskan bagaimana menggunakan software dalam percobaan (3) siswa perlu lebih banyak diberi kesempatan berpikir dalam mengemukakan pendapat dan bertanya serta melakukan percobaan atau demonstrasi dengan menggunakan software (4) merangkum atau menyimpulkan pelajaran sebaiknya melibatkan siswa, bukan oleh guru sendiri.

\section{Siklus II}

Data yang didapat dari kegiatan pembelajaran pada siklus II adalah sebagai berikut: (1) siswa mulai aktif di dalam pembelajaran listrik dinamis, penggunaan software komputer telah membantu pemahaman konsep diakibatkan guru mulai mengajar secara terarah dan berstruktur, (2) hasil evaluasi yang dilakukan guru setelah pembelajaran berlangsung, yaitu hasil belajar siswa mengalami peningkatan yaitu rata-rata $71,13 \%$ dapat dilihat pada tabel 1, (3) hasil lembar monitoring implementasi virlab berbasis komputer yang menunjukkan penilaian kinerja siswa mengalami peningkatan siswa dapat mendisain rangkaian dan kreativitas siswa meningkat tetapi ketelitian pengukuran dan penggunaan alat masih perlu diperhatikan hasil penilaiannya dapat dilihat pada tabel 2 .

Dari hasil refleksi disimpulkan Penyajian materi dengan menggunakan software komputer (simulasi komputer) membuahkan hasil positif yang dilanjutkan dengan praktikum dengan implementasi virtual laboratorium berbasis komputer namun belum sepenuhnya mampu mengaktifkan siswa diperlukan solusi yaitu: (a) Pada awal pembelajaran guru perlu menarik dan mengarahkan perhatian siswa pada pokok pelajaran yaitu dengan menjelaskan tujuan pembelajaran pada kegiatan yang akan dilakukan Guru melakukan demonstrasi mengenai tekhnik pelaksanaan pembelajaran termasuk cara menggunakan program simulasi (modul virtual laboratorium berbasis komputer) yang ada yang digunakan sebagai suplement pembelajaran listrik dinamis (b) Guru memberikan kesempatan kepada siswa untuk merangkum atau menyimpulkan pelajaran yang diperoleh siswa dari simulasi dan praktikum dengan implementasi virtual laboratorium berbasis komputer (c) Siswa perlu diberikan pembelajaran operasi matematika dan juga penekanan akan pemahaman konsep.

\section{Siklus III}

Data yang didapat dari kegiatan pembelajaran pada siklus III adalah sebagai berikut: (1) guru menyampaikan materi dengan baik sehingga siswa lebih tertarik untuk mengikuti proses pembelajaran (terdapatnya perangkat pembelajaran RPP, silabus dan juga petunjuk menggunakan CD Virlab), (2) hasil evaluasi yang dilakukan guru setelah pembelajaran berlangsung, yaitu hasil belajar siswa mengalami peningkatan yaitu rata-rata $83,35 \%$ dapat dilihat pada tabel 1, (3) hasil lembar monitoring implementasi virlab berbasis komputer yang menunjukkan penilaian kinerja siswa mengalami peningkatan dengan tersedianya modul virtual laboratorium berbasis komputer dalam bentuk CD ditunjukkan dengan hasil yang tinggi. Hasil penilaiannya dapat dilihat pada tabel 2.

Berdasarkan hasil data terjadi peningkatan hasil belajar tetapi belum optimal, kelemahan mendasar yang ditemukan adalah masih kurangnya waktu yang ditetapkan dalam pelaksanaan pembelajaran, apalagi sebagian waktu latihan yang dimanfaatkan untuk mendemonstrasikan penggunaan software. Pada siklus ketiga ini, hampir secara keseluruhan permasalahan yang dihadapi siswa telah dapat diatasi dengan baik, tetapi pengoperasian matematika pada fisika perlu diperhatikan.

Paparan hasil pembelajaran dari observasi awal, pretest, post test, lembar 
monitoring virtual laboratorium, hasil belajar, test akhir keterlaksanaan dan ketercapaian tahapan pembelajaran dengan implementasi virtual laboratorium berbasis komputer dapat dilihat pada tabel 1,2,3

Tabel 1. Hasil Penilaian Kinerja Siswa dengan Implementasi Virtual Laboratorium Berbasis Komputer

\begin{tabular}{|l|c|c|c|}
\hline Hasil Test & Siklus I & Siklus II & Siklus III \\
\hline Skor terendah & 78 & 80 & 86 \\
\hline Skor tertinggi & 103 & 129 & 140 \\
\hline Ketuntasan & $62,16 \%$ & $81,08 \%$ & $100 \%$ \\
\hline Rata-rata & 60,75 & 77,39 & 87,74 \\
\hline
\end{tabular}

Tabel 2. Hasil Tes Belajar Siswa SMP Negeri 9 kelas IX-5

\begin{tabular}{|l|c|c|c|}
\hline Hasil Test & Siklus I & Siklus II & Siklus III \\
\hline Skor terendah & 34 & 49 & 59 \\
\hline Skor tertinggi & 65 & 86 & 95 \\
\hline Ketuntasan & $48,64 \%$ & $78,37 \%$ & $94,59 \%$ \\
\hline Rata-rata & 51,08 & 71,13 & 83,35 \\
\hline
\end{tabular}

Keterlaksanaan dan ketercapaian tahapan pembelajaran dengan model pembelajaran berbasis komputer dapat dilihat pada table 3

Tabel 3. Persentase Keterlaksanaan dan Ketercapaian Tahapan Pembelajaran

\begin{tabular}{|l|c|c|l|}
\hline Siklus & Keterlaksanaan (\%) & Ketercapaian (\%) & \multicolumn{1}{c|}{ Materi } \\
\hline I & 100 & 68,65 & Arus listrik dan tegangan listrik \\
\hline II & 100 & 86,15 & Hukum ohm, hambatan jenis \\
\hline III & 100 & 95,90 & $\begin{array}{l}\text { Hukum kirchoff, rangkaian seri } \\
\text { \& paralel hambatan }\end{array}$ \\
\hline
\end{tabular}

Tabel 4. Daftar Distribusi Peningkatan Skore pada Tes awal dan Tes akhir

\begin{tabular}{|c|c|c|c|}
\hline Range Nilai & Frek. Test awal & Frek. Test akhir & Indikator keberhasilan \\
\hline$\leq 59$ & 37 & 2 & Kurang \\
\hline $60-75$ & - & 3 & Cukup \\
\hline $76-99$ & - & 32 & Optimal \\
\hline 100 & - & - & Istimewa \\
\hline Jumlah & 37 & 37 & \\
\hline
\end{tabular}

Hasil belajar siswa dianalisis menggunakan gain score ternomalisasi dengan data pre test dan post test maka di dapat $\mathrm{g}=0,8$ tergolong tinggi (Lampiran 8), dari uji hipotesis di dapat $\mathrm{t}_{\text {hitung }}=44,86$ (lampiran 12 ) dengan $\mathrm{t}_{\text {tabel }}$ $=2,04$ Dengan taraf signifikansi $5 \%$ yang berarti $t_{\text {hitung }}>t_{\text {tabel }}=44,86>2,04$ yang berarti hipotesa diterima atau ada peningkatan yang signifikan terhadp kualitas belajar siswa melalui implementasi virtual laboratorium berbasis komputer.

\section{Pembahasan}

Berdasarkan analisis data yang diperoleh, terlihat bahwa kualitas belajar siswa mengalami peningkatan pada mata pelajaran listrik dinamis dengan implementasi virtual laboratorium berbasis komputer. Pembelajaran ini juga dapat memecahkan masalah yang dihadapi siswa dalam proses pembelajaran. Hal ini dimungkinkan dengan menggunakan program animasi dan simulasi menciptakan suasana belajar yang menyenangkan dan mengupayakan siswa memperoleh pengetahuan, 
pengalaman, penerapan dan memperoleh informasi lebih banyak dari program yang ada. Penggunaan software komputer pada proses pembelajaran fisika mendorong siswa untuk menggali kemampuannya yang dituangkan dalam percobaan melalui implementasi virtual laboratorium berbasis komputer.

Kualitas belajar siswa yang ditunjukkan dengan hasil belajar siswa, Penguasaan konsep, keterampilan berpikir kreatif dan keterampilan proses sains disemua kelompok kemampuan meningkat secara merata. Artinya Implementasi Virtual laboratorium berbasis komputer pada pembelajaran listrik dinamis yang dikembangkan memberikan pengaruh yang sama untuk semua kelompok kemampuan dalam meningkatkan kualitas belajar siswa.

Simulasi komputer dalam eksperimen laboratorium adalah tidak mengganti prosesnya secara actual akan tetapi sebagai alat untuk digunakan untuk memahami fenomena rangkaian elektronika. Simulasi komputer adalah disiplin mendesain model sistem fisik yang sebenarnya atau secara teoretis, melakukan model di dalam komputer digital, dan analyzing hasil pelaksanaan. Dari definisi dasar ini, didapat tiga bagian dalam simulasi komputer, yaitu: (1) pola model, (2) Implementasi model dan , (3) analisa pelaksanaan.

Pengajaran berdasarkan simulasi komputer adalah didasari inkuiri yang merupakan suatu strategi yang berpusat pada mahasiswa di mana kelompok-kelompok siswa dihadapkan pada suatu persoalan atau mencari jawaban terhadap pertanyaan-pertanyaan di dalam suatu prosedur dan struktur kelompok yang digariskan secara jelas Inkuiri merupakan suatu cara mengajar murid-murid bagaimana belajar dengan menggunakan keterampilan, proses, sikap, dan pengetahuan berpikir rasional (Bruce \& Bruce, 1992). Cleaf (1991) menyatakan bahwa simulasi komputer adalah salah satu strategi yang digunakan dalam kelas yang berorientasi proses. simulasi komputer merupakan sebuah strategi pengajaran yang berpusat pada mahasiswa, yang mendorong mahasiswa untuk menyelidiki masalah dan menemukan informasi. Proses tersebut sama dengan prosedur yang digunakan dalam menyelidiki masalah-masalah dan menemukan informasi.

Menurut Carrol dalam Bloom (1977) yang mengatakan bahwa penguasaan materi pelajaran yang terpenting adalah diberikannya waktu yang cukup bagi si pelajar untuk menguasai pelajarannya. Oleh karena waktu yang digunakan lebih banyak lagi, bagi mereka yang memperoleh perlakuan pembelajaran, maka hal ini berarti bahwa pengalaman belajar siswa lebih banyak pula, dan kondisi ini dapat membuat siswa untuk memperoleh kualitas belajar yang baik.

Berdasarkan analisis data tanggapan siswa terhadap implementasi virtual laboratorium berbasis komputer ini terdapat temuan-temuan yang positif. Siswa merasa senang dengan situasi belajarnya, siswa terlibat aktif secara mental dalam mengemukakan pendapat, gagasan atau menyampaikan suatu argumentasi, siswa lebih mudah memahami konsep, dan termotivasi untuk meningkatkan keterampilan berpikirnya. Selama ini pelajaran IPA kuhususnya fisika di SMP negeri 9 kurang diminati karena direpotkan dengan pengoperasian matematika, rumus-rumus dan pemahaman konsep, siswa semakin antusias belajar Fisika, Implementasi ini juga membantu guru dalam proses pembelajaran secara efektif dan efisien.

\section{PENUTUP \\ Simpulan}

Berdasarkan hasil analisa data dan pembahasan dapat diambil kesimpulan bahwa : Pembelajaran Listrik dinamis dengan implementasi virtual laboratoratorium berbasis komputer dapat meningkatkan kualitas belajar dan sebagian besar siswa merasa senang dan termotivasi untuk belajar.

\section{Saran}

Guru diharapkan dapat membuat modul virtual laboratorium berbasis komputer, Bila perlu guru dapat mengadopsi dari internet atau mengadaptasi strategi pembelajaran yang telah terbukti efektif dan mengkomunikasikannya dengan kolega.

\section{DAFTAR PUSTAKA}

Arsyad, A. (2007). Media Pembelajaran.Jakarta: PT. Raja Grafindo Persada.

Arikunto, S. (2012), Dasar-dasar Evaluasi Pendidikan. Jakarta : Rineka Cipta

Aufschnaiter, C. V and Christian Rogge. (2010). Misconceptions or Missing Conceptions?.Justus Liebig University Giessen, Giessen, GERMANYEurasia 
Journal of Mathematics, Science \& Technology Education, 2010, 6(1), 3-18

Arends, R.I. (2009). Learning to Teach $7^{\text {th }}$.ed. Singapore: Mc Graw Hill.

Bayrak, B. The Compare the Effects of Computer Based Learning and The Laboratory Based Learning on Students Achievement Regarding Electric Circuits. Gazi University.The Turkish Online Journal of Educational Technology - TOJET January 2007 ISSN : 1303-6521 volume 6 Issue 1 Article 2

Dick, W., \& Carey, L. (2005). The Systematic design of Instruction. $6^{\text {th }}$ edition.Pearson :Amerika

Gardner, H. (2011). The Theory Of Multiple Intelligences. New York : Basic Books

Haron, Saharudin. Numerical Methods for Chemical Engineers. Course Material for Chemical Engineering Numerical Method.PSE - FKKKSA, Universiti Teknologi Malaysia.
Hergenhahn, B.R. dan Matthew, H. Olson., (2009). Theories of Learning.Jakarta : Kencana.

Heinich, Molenda and Russel (1993).Instructional Media.Macmillan Publishing Company.

Gryphon Software Corporation (1996). Gryphon Bricks Demo (Version 1.0) [Computer Software]. Glendale, CA: Knowledge Adventure. [Online]Available:http://www.kidsdomain.co $\mathrm{m} /$ down/mac/bricksdemo.html

Hackworth (2002. Uncovering the creative dimensions of computer-graphic design products.

Surakhmad, W. (1994). Pengantar Interaksi Mengajar, dasar dan tekhnik Metodologi Pengajaran, Bandung, Tarsito

Slavin, Robert E. (2006). Educational Psychology : Theory And Practice $8^{\text {th }}$. USA : Pearson Education, Inc. 